\title{
Perubahan Sosial dalam Pergeseran Sistem Kegotongroyongan di Daerah Minangkabau
}

\section{Firman Firman \\ Jurusan Bimbingan dan Konseling Universitas Negeri Padang Email : firman@konselor.org}

\section{A. Pendahuluan}

Masyarakat Minangkabau dewasa ini sebagian besar menempati Daerah Tingkat I Propinsi Sumatera Barat, yang secara Geografis dibatasi oleh Lintang Selatan antara $0^{0} 54^{\prime}-3^{0} 30$ 'dan Bujur Timur antara $98^{0} 36-101^{0} 53^{\prime}$. Secara budaya daerah Minangkabau melampaui batas georafis dan geopolitik administrasi Negara Indonesia, yaitu sampai ke Negeri Sembilan Malaysia. Sehubungan dengan itu, penyebaran masyarakat Minangkabau sampai ke daerah Riau, Kuala Tungkal, Muko-muko dan daerah lain yang menjalankan budaya Minangkabau dalam kehidupan sehari-hari.

Ciri yang menonjol dari masyarakat Minangkabau dibandingkan dengan masyarakat lainnya, diantaranya sistem kekerabatan matrilinial dengan menelusuri ikatan kekerabatan melalui garis ibu. Sistim kekerabatan matrilinial Minangkabau mempunyai ciri-ciri sebagai berikut : (1) keturunan dan pembentukan kumpulan diperhitungkan menurut garis keturunan ibu, (2) perkawinan bersifat matrilokal; (3) anggota kelompok kerabat merasa bersaudara kandung, senasib, sehina, semalu; (4) kekuasaan hakiki pada ibu dan kekuasaan teknis pada mamak dalam kaum dan suku; (5) pola tempat tinggal bercorak dwilokal; (6) kesatuan keluarga terkecil adalah paruik yang bersifat geneologis; serta (7) pusaka tinggi turun dari mamak 
kepada kemenakan (Malinowsky dalam Rajab, 1969:17; Kato, 1989:54-55; Mardanas, 1991:9-10).

Sejah peristiwa PRRI tahun 1960 dan sampai sekarang harus masyarakat Minangkabau untuk merantau sangat deras, akibatnya penghuni kampung atau nagari hanya orang tua atau anak-anak saja lagi. Tanah produktif yang ada, sebagian dibengkalaikan dan tidak dikelola. Anak muda banyak yang enggan untuk mengolah tanah produktif tersebut untuk pertanian. Sebagian kebun-kebun yang ada banyak tidak dikelola secara kontiniu dan ditanami dengan tanaman tua, seperti: kelapa, kulit manis dan sebagainya. Masyarakat pergi merantau sebagai tuntutan budaya dan setiba di rantau pekerjaan yang dipilih, seperti berjaja kain, barang perhiasan yang tidak terlalu mahal atau barang lain tampak cantik dan cepat laku menjadi pekerjaan yang menarik bagi mereka. Bagi masyarakat yang tinggal di kampong, mereka bertani ( bersawah, berladang serta pengrajin dan sebagainya). Walaupun demikian pertanian yang berlangsung di daerah ini berskala kecil karena kondisi lahan yang berbukit dan berlembah tidak memungkinkan dikembangkan pertanian skala besar.

Pemanfaatan tenaga kerja bagi masyarakat Minangkabu yang bermata pencaharian sebagai petani dan pengrajin, awalnya dilakukan melalui bantumembantu yang dikenal dengan sistim gotong royong. Kegiatan gotong royong dalam masyarakat Minangkabau akan terlihat dalam bidang pertanian, terutama untuk pekerjaan bercocok tanam secara tradisional dalam komunitas pedesaan. Sistem gotong royong yang dilaksanakan masyarakat Minangkabau dalam mengerakkan tenaga kerja berpegang teguk kepada adat dan kebiasaan Minangkabau sebagai benteng kehidupan mereka. Filsafat hidup yang dianut sehubungan dengan kehidupan 
gotong royong ini yaitu : bakato baiyo, bajalan bamolah. Artinya memutuskan sesuatu dengan mufakat dan perundingan.

Pepatah tersebut mengambarkan kuat dan kokohnya rasa kegotong royongan dalam masyarakat Minangkabau. Perwujudan sistem kegotongroyongan dalam bidang pertanian bagi masyarakat Minangkabua dalam pengolahan lahan pertanian dikerjakan secara bersama-sama. Sawah di kerjakan di bawah bimbingan mamak. Bersama-sama dengan kemenakan laki-laki, orang sumando dan sumbayan dalam porsi kategori berat, misalnya mencakul, membajak, menyabit dan mengiriak. Sampai membawa padi pulang ke rumah habis panen dan dimasukan ke dalam lumbung dikerjakan eleh kaum laki-kaki secara bergotong royong. Pekerjaan yang ringan seperti: menaman, mengiray dan mengangin dilakukan oleh perempuan secara bersama pula dengan sistem goton royong antar kaum wanita, sedangkan anak-anak bertugas menggaro pipik (memburu burung pemakan padi).

Sistem pengarahan tenaga kerja seperti diuraikan di atas tidak banyak di daerah Minangkabua, tetapi terdapat di daerah lain di dunia. Dimana Produksi bercocok tanaman secara tradisional masih dominat. Misalnya komunitas pedesan suku bangsa, penduduk Afrika, asia dan Oceania dan penduduk pribumi di amerika Latin. Kehiupan gotong royong sampai hari ini masih ada, bahkan terdapat juga di beberapa tempat di Eropa (Kontjaraningrat, 1994).

Selain di daerah Minankabau di Pulau Jawa sistem kegotongroyongan bedanya hanya dilakukan untuk pekerjaan yang meliputi perbaikan pematang dan saluran air, mencangkul dan membajak, menanam dan membersihkan sawah dari tumbuh-tumbuhan liar. Pekerjaan memotong padi digunakan tenaga wanita dan 
anak-anak yang diberi upah. Di banyak daerah di luar Pulau Jawa sistem gotong royong dalam bercocok tanam telah berkurang dan diganti dengan sistem perburuhan. (Koentjaraningrat 1994).

Bertitik tolak dari uraian di atas, terlihat semagat bergotongroyong adalah salah satu warisan nenek moyang dan pola hidup bangsa Indonesia. Dewasa ini bila diamati di daerah Minangkabua tanda-tanda mulai lunturnya nilai gotong royong sudah mulai nampak, meskipun tidak mengkhawatirkan. Perubahan pola kehidupan tersebut, disebabkan adanya kontak antara satu budaya dengan budaya lainnya, kesempatan memperoleh pendidikan seluas-luasnya, perubahan struktur pemerintahan dan kemajuan teknologi.

Akhir-akhir ini masyarakat Minangkabau merasakan uang merupakan unsur penting dalam kehidupan. Kondisi ini ikut mempengaruhi budaya masyarakat pedesaan Minangkabau, pemikiran materialisme yang berpatokan bahwa manusia adalah makhluk ekonomi telah mulai merasuki kehidupan masyarakat. Sebagian masyakat di pedesaan sudah mulai meninggalkan adat gotong royong dalam produksi pertanian sedangkan di daerah perkotaan system gotong royong mulai luntur dan terkena erosi sebagi akibat proses industrialisasi.

Akhir-akhir ini pergeseran sistem kegetongroyongan menjadi sistem perburuhan tanpa disadari semakin jelas, unsur-unsur tertentu dalam kehidupan masyarakat yang dulunya dilakukan secara bersama-sama dengan gotong royong, hari demi hari telah bergeser ke sistem perburuhan. Awalnya sistem kehidupan semacam ini terasa agak asing dan janggal di pandang mata. Lama kelamaan menjadi kebiasaan yang harus diterima yang didorong oleh beberapa hal, baik yang bersumber dari 
faktor interen maupun eksteren. Makalah ini akan berusaha memaparkan pergeseran sistem kegotongroyongan menjadi perbutuhan di Minangkabau.

\section{B. Sistem Kegotongroyongan dalam Masyarakat Minangkabau}

Konsepsi dan pengertian gotong royong selaku sistem kerja yang mengacu kepada perwujudan solidaritas nasyarakat dalam kehidupan sosial, merupakan salah satu citi khas masyarakat pedesaan. Sebagaimana diungkapkan B. Malinoswski : principle of receprocity, yaitu kewajiban membalas yang merupakan dasar motivasi tolong menolong dalam berbagai bidang kehidupan masyarakat dan berfungsi untuk memelihara solidaritas serta integrasi dalam masyarakat.

Durkheim melalui teorinya tentang pembagian kerja dalam masyarakat, mengungkapkan masyarakat sederhana dimana seolah-olah tidak ada pembagian kerja sesama anggota dalam masyarakat. Dengan demikian mengandung arti bahwa fasilitas -fasilitas yang bernilai ekonomi adalah milik bersama. Aktifitas gotong royong sudah digerakan karena yang diutamakan adalah susila umum dengan demikian kontrak sosial amat kuat. Begitu pula sebaliknya bagi masyarakat yang moderen dan komplek.

Apabila dikaitkan denegan nilai budaya masyarat Indonesia. Koentjaraningrat (1994) mengemukakan sistem nilai budaya dalam sub konsep : (1) manusia tidak hidup sendiri-sendiri di dunia ini, tetapi dilingkupi oleh komunity dan alam sekitarnya. Dalam sistem makrokosmos ia merasakan dirinya hanya sebagian unsur kecil saja, yang ikut terbawa oleh proses peredaran alam semesta yang maha besar ini , (2) manusia pada hakekatnya dalam segala aspek kehidupan tergantung sesamanya, (3) ia selalu berusaha untuk sedapat mungkin memelihara hubungan baik 
dengan sesamanya yang didorong oleh jiwa sama tinggi dan sama rendah, sama rasa dan sama-sama, (4) selalu berusaha sedapat mungkin bersifat konform, perbuatan sama dan bersama dalam komitnya yang didorong oleh hubungan sama tinggi dan sama rendah.

Berdasarkan konsep tersebut di atas, bila diimplikasikan dalam kehidupan bergotongroyong, konsep tersebut mengandung nilai budaya dan sistim tindakan. Sistim nilai budaya merupakan suatu sistim yang berfungsi sebagai penuntun sikap dan tindakan sosial masyarakat. Sedangkan sistem tindakan merupakan peranan sosial yang diwujudkan dalam kegiatan gotong royong. Sistim ini akan terlihat dalam berbagai bidang kehidupan, misalnya dalam kehidupan ekonomi, peralatan, kemasyarakatan dan kepercayaan. Sistim tindakan dan sistim nilai budaya tidak dapat dipisahkan antara satu dengan lainnya dan masing-masing sistim saling berkaitan. Kalau kita perhatikan konsep gotong royong mengandung nilai yang tinggi dan erat sangkut pautnya dengan kehidupan rakyat sebagai petani dan kehidupan masyarakat agraris..

Kegiatan gotong royong mengacu kepada satu jenis perwujudan solidaritas sebagai masyarakat pedesaan. Bila prinsip solidaritas telah berlaku, prinsip timbal balik yang sudah cukup membudaya maka timbulah pertukaran umum yang mengandung prinsip sistim pengarapan atau pekerjaan dengan pertukaran tenaga atau barang, pertukaran antara barang dengan barang.

Teori pertukaan sosial menyatakan bahwa pertukaran sosial menimbulkan suatu kode moral untuk kelakukan anggota masyarakat yang mempunyai eksistensi sendiri terlepas dari situasi pertukaran sosial sendiri. Kekuatan utama yang 
mempegaruhi hubungan antar pribadi adalah moralalitas pertukaran, oleh sebab itu moralitaas pertukaran mempunyai pengaruh jauh lebih luas dan senantiasa menjadi dasar hubungan sosial. Dalam masyarakat pedesaan pertukaran sosial tidak terbatas pada pertukaran sosial yang langsung mendapat balasan, proses pertukaran sosial bersama moralitas yang ditimbulkannya dengan dorongan jaringan komunikasi kultural. Pelaksanaan gortong royong dilakukan oleh sekelompok orang di suatu daerah yang membantu menawarkan tenaga tanpa pamrih atau dengan perkataan lain secara sukarela bersama-sama sehingga semua anggota masyarakat akan berkerja dengan senang hati dan pekerjaan itu akan selesai dengan cepat dapat diselesaikan.

Kebersamaan semacam tersebut di atas telah dilaksanakan di Minangkabau secara berat dan berangkat. Hal ini dapat dilihat dari pameo yang dijadikan fisafat hidup yang berhubungan dengan kegotongroyongan, yaitu : Sadanciang bak basi, saciok bak ayam. Pameo semacam ini menggambarkan kokohnya sistem kegiat kegotongroyongan pada masyarakat Minangkabau.

\section{Perubahan Sosial dan Sistem Perburuh di Minangkabau}

Adat Minangkabau mengakui kemungkinan terjadinya perubahan-perubahan dalam tata kehidupan masyarakat, sesuai dengan pepatah yang dijadikan sebagai pegangan hidup, yaitu : Sakali ai gadang, sakali tapian barubah, namun ai kahilia juo. Sakali gadang batuka, sakali paraturan barubah, namun adaiak baitu juo.

Masyarakat Minangkabu telah banyak mengalami perubahan, struktur masyarakat yang tersusun dalam bentuk lingkaran kekerabatan atas garis keturunan Ibu, telah mengalami perubahan. Keluarga inti yang terdiri dari ibu bapak dan anak- 
anaknya semakin menonjol dibandingkan dengan keluarga luar. Sistim milik juga mengalami pergeseran, dimana harta pencaharian semakin nampak dimana harta pusaka semakin tidak bertahan (Firman, 1997)

Di samping itu, basis perekonomian masyarakat Minangkabau, yang dulunya bertani mengalami pergeseran dengan bertambah pentingnya sektor lain. Dewasa ini semakin banyak masyarakat Minangkabau tidak hidup di sektor agraris lagi, dengan semakin meningkatnya keterampilan dan mobilitas sosial. Kondisi ini menyebabkan terjadinya perubahan dalam berfikir dan bertingkah laku serta hubungan antara satu dengan lainnya.

Selain faktor biologis, faktor kebudayaan dan teknologi turun menentukan perubahan sosial dalam masyarakat. Ralp Linton mengemukakan berkat adanya berbagai penemuan dan inovasi baru senantiasa melibatkan berbagai akibat sosial yang sebahagian dapat dikategorikan sebagai perubahan sosial (Ralp Linton : 1962).

Bila dikaitkan dengan perubahan sosial yang terjadi di daerah Minangkabau, didorong oleh hal-hal sebagai berikut : Kontak dengan kebudayaan lain, sitem pendidikan yang maju, sikap menghargai hasil karya seseorang dan keinginan untuk maju. Toleransi terhadap perbuatan-perbuatan yang menyimpang, sistem lapis sosial yang terbuka dan penduduk yang heterogen. Kondisi ini menyebabkan kian hari di dalam masyarakat Minangkabau terjadi pergeseran nilai kegotong royongan menjadi sistem perburuhan.

Perubahan sosial yang terjadi dalam masyarakat Minangkabau dengan semakin menonjolnya sistem perburuhan, terlihat dalam hal : 


\section{Perubahan Kebudayaaan}

Perubahan sosial pada masyarakat pedesaan telah di awali sejak terjadinya kontak antara satu budaya dengan budaya lainnya serta meluasnya kesempatan memperoleh pendidikan. Tingkat pendidikan masyarakat membawa perubahan besar dalam memandang suatu persoalan. Kemajuan pendidikan masyarakan Minangkabau terlihat dari sarana pendidikan yang digunakan. Dewasa ini masyarakat tidak menggunakan surau atau langgar lagi sebagai tempat mendidik anak-anak mereka. Disamping itu anak-anak remaja yang sedang meningkat dewasa dengan sendirinya tidak tidur di surau lagi seperli masa silam. Sebagian besar anak-anak tersebut, telah menggunakan waktunya untuk menggulang pelajaran dan membantu pekerjaan orang tua dimalam harinya di rumah bersama orang tua dan saudara lainnya.

Sebelum pendidikan formal ada di lingkungan masyarakat Minangkabau, anak remaja laki-laki secara adat dilarang tidur di rumah orang tua bersama dengan adik dan kakak perempuannya. Apabila hal ini terjadi, dianggap aib bagi si laki-laki remaja tersebut. Mereka harus tidur di surau/langgar untuk belajar mengaji, bersilat, sopan santun serta adat istiadat Minangkabau. Dewasa ini nenek-nenek tidak perlu lagi memberikan pendidikan pada anak-anak dengan memberikan cerita - cerita, mereka telah memperolehnya di sekolah sebagai pranata pendidikan bagi masyarakat.

Dengan demikian pendidikan keluarga mulai tersingkir secara per lahanlahan dan akhirnya secara berangsur-angsur hilang. Begitu juga halnya dengan kegiatan gotong royong mulai berubah karena makin kompleknya pekerjaan 
yang harus diselesaikan dibandingkan dengan waktu yang ter sedia. Melalui pendidikan lahirlah dua golonggan dalam masyarakat Minangkabau. Golongan pertama yaitu golongan orang tua yang masih memegang adat istiadat lama dan golongan kedua yang sudah moderen. Kedua golongan tersebut menginterpretasikan dan memahami lingkungan secara berbeda. Bagi golongan orang tua menarik sesuatu kesimpulan dari suatu mala petaka dari segi kepercayaan lama (tahyul), anak sakit, meninggal, panen gagal, bencana alam menurut mereka karena kesalahan-kesalahan dalam hidup dan dimarahi roh halus karena disebabkan tidak mematuhi apa yang dituntut oleh roh halus tersebut.

Sementara itu golongan moderen melihat anak sakit, minggal karena kurang penjagaan kesehatan. Kepercayaan-kepercayaan terhadap tempat-tempat yang keramat dan orang keramat, seperti dukun tidak ada lagi dalam kehidupan orang moderen. Dimana-dimana telah ada PUSKESMAS dan dokter yang membuka praktek. Bila masyakat membutuhkan asal ada uang kebutuhan akan terpenuhi untuk mengobati sesuatu penyakit yang dialami. Pergeseran sistem kekeluargaan terhadap dukun secara lambat laun terjadi. Dengan kondisi semacam ini masyarakat sudah mulai melakukan sesuatu yang membawa dampak untuk kepentingan pribadi karena keluarga inti mulai menonjol dibandingkan dengan keluarga luas.

Faktor lain yang membawa perubahan, yaitu berkembangnya konsep NKKBS (Nilai Keluarga Keeil Sejahtera dan Bahagia) dalam masyarakat. NKKBS menghendaki dua anak cukup, laki-laki dan perempuan sama saja. 
Norma ini membawa perubahan orientasi berfikir masyarakat Minangkabau, yaitu :

a. Konsep atau gagasan banyak anak banyak rezeki kian memudar. Nilai ekonomi tidak ditentukan banyak anak, tetapi sebaliknya sedikit anak menentukan nilai lebih dari rezeki yang didapat kedua orang tuanya. Makin sedikit tanggungan keluarga maka makin sejahteralah keluarga tersebut.

b. Ibu rumah tangga tidak lagi bangga dengan predikat sebagai ibu rumah tangga. Bila orang ber tanya dimana dan apa perkerjaannya dan ia menjawab di rumah saja sebagai ibu rumah tangga. Perempuan Minangkabau berpandangan istri yang ideal, adalah istri yang membantu suami bekerja dalam rangka menjamin masa depan anak-anak.

c. Pembahagian kerja suami istri yang didasarkan prinsip pembahagian kerja secara seksual, yang mana suami mencari uang kemudian istri mengatur di rumah kian berubah. Tata nilai Orang Minangkabau yang berpandangan setinggi pendidikan wanita akan ke dapur juga mulai pudar, jabatan jabatan penting di Minangkabau sudah mulai dijabat Wanita. Contoh direktur Bank, Dekan dan beberapa tugas penting lainnya.

\section{Teknologi dan Perubahan Sosial}

Penemuan teknologi membawa efek terhadap kehidupan masyarakat Minangkabau.Teknologi pada hakekatnya merupakan cara dan alat yang digunakan dalam menerapkan prinsip-prinsip ilmu pengetahuan guna kepentingan mencapai sasaran yang diinginkan. Dengan perkataan lain teknologi merupakan 
penerapan ilmu pengetahuan untuk tujuan-tujuan praktis. Selama ini Masyarakat Minangkabau menggunakan tangan manusia bersama alat-alat yang bersifat sederhana dengan kekuatan terbatas. Sekarang dengan kemajuan teknologi telah menggunakan alat-alat yang canggih dengan memanfaatkan kekuatan listrik. Dengan demikian produksi meningkat, beberapa perusahaan kecil mulai tergusur oleh perusahaan besar. Kebutuhan akan tenaga kerja mulai dirasakan, pada akhirnya karena keterbatasan tenaga kerja yang ada maka diambil dari luar daerah. Tenaga yang bekerja di bidang pertanian semakin berkurang, dengan sendirinya sistem gotong royong mulai berkurang karena orientasi masyarakat sudah mulai berubah kearah uang sebagai sasaran utama.

Di bidang pertanian juga demikian, disana-sini mulai adanya pemakaian bibit unggul, pupuk, traktorisasi, pembasmian hama, komunikasi dan tranformasi informasi melalui Tv dan Video. Kita akan menemukan penggunaan teknologi traktor dalam mengerjakan sawah, penggunaan alat ini akan membawa dampak pada peranan lembaga-lembaga sosial dan gaya hidup masyarakat pedesaan di Minangkabau dewasa ini. Pemakaian alat ini akan meningkatkan produksi empat sampai lima kali lipat, dengan sendirinya tidak membutuhkan tenaga yang banyak untuk menuai dan menyabit serta mengolahnya. Timbulah pranata baru yaitu hubungan buruh dengan majikan tidak lagi bersifat kekeluargaan tetapi didasarkan tatanan ekonomis.

Kenaikan hasil produksi yang paling utama menikmati adalah petani pemilik. Sedangkan kenaikan gaji petani tidak seimbang dengan kenaikan harga yang dihadapinya untuk kebutuhan bahan pokok sehari-hari. Dengan demikian 
pemakaian teknologi pertanian cenderung menggeser sejumlah petani penggarap dan sebagian lapangan kerja mulai hilang.

\section{Penutup}

Sistem kegotongroyongan merupakan sistem nilai budava masyarakat Indonesia. Melakukan kegiatan gotong royong merupakan tinadakan sosial yang dapat dilihat dalam berbagai bidang kehidupan, yang dilaksanakan dalam bentuk kelompok yang sifatnya saling membantu. Kegiatan semacam itu telah membudaya di daerah Minangkabau sejak masa silam. Kondisi ini dibuktikan oleh filsafat hidup yang dianut masyarakatnya yang diwujudkan dalam bentuk pepatah dan petitih, misalnya :"sadan ciang bak basi, ka bukik samo mandaki ka lurah sama manurun.

Pergeseran sistem kegotongroyongan menjadi sistem perburuhan di daerah Minangkabau disebabkan oleh beberapa faktor, antara lain : (1) semakin menonjolnya keluarga inti, sehingga peran Bapak semakin nampak bila dibandingkan dengan peranan mamak. Di samping itu harta pencaharian semakin menonjol di bandingkan dengan harta pusaka.

Basis kehidupan masyarakat yang dulunya dari pertanian bergeser ke bidang lain dengan semakin meningkatnya keterampilan dan ilmu pengetahuan. Secara umum perubahan tersebut juga disebabkan oleh faktor teknologi, kalau dulunya pengerjaan kerajinan memakai alat-alat tradisional sekarang telah ditemukan mesin-mesin yang memungkinkan membuat dalam bentuk partai besar, begitu juga dalam bidang pertanian, sehingga membutuhkan tenaga yang banyak. Kebebasan untuk memperoleh pendidikan, kalau dulunya surau atau langgar 
dijadikan tempat pusat pendidikan, sekarang telah diganti dengan lembaga pendidikan formal, akibatnya anak laki-laki yang biasanya secara adat harus tidur di surau atau di mesjid setelah menyelang dewasa tidak ada lagi karena banyak bidang pekerjaan yang harus diselesaikan, akibatnya adat istiadat mulai bergeser. 


\section{Daftar Kepustakaan}

Bintoro (1980) : Gotong Royong, Suatu Karakteristik Bangsa. Surabaya : PT Bina Ilmu.

Doyle, Paul Johnson (1986): Teori Sosiologi Klasik dan Moderen Cterjemahan). Jakarta : PT. Gramedia.

Davis Keingsley (1980) : Human Society. Newyork : The Me Millan Company.

Eva Etzioni, Hulwy and Amitai Etzioni (1983): Social Change. Newyork : Basic Books, Ins.

Firman (2004) : Perubahan Fungsi Mamak dalam Sistem Kekerabatan Matrilinial. Padang : FIP Univ.Negeri Padang.

Hasan Basri Durin (1994) : Berbagai Masalah dalam Perwarisan dan Pengembangan Adat Minangkabau. Bandung : Madju.

Koentjaraningrat (1994) : Masyarakat Desa di Indonesia, Jakarta : Lembaga Penerbit Akuntasi Ekonomi UI.

, (1990) : Manusia dan Kebudayaan di Indonesia. Jakarta : Penerbit
Jambatan.
Gramedia.

, (1990) : Manusia dan Kebudayaan di Indonesia. Jakarta : Penerbit
Jambatan.
Gramedia.

, (1992) : Masalah-masalah Pembangunan, Bunga Rampai Antropologi Terapan. Jakarta : LP3ES. 